\title{
STATE OPERATIONS IN GOLD AND FOREIGN EXCHANGE*
}

\author{
Edward Ames $\dagger$
}

\section{INTRODUCTION}

This paper discusses the implications of state transactions in gold and foreign exchange. As used here, the term government includes (a) central banks, (b) treasuries, and (c) exchange-stabilization and exchange-control authorities. ${ }^{1}$ Gold today is held mainly in bars of about ninety-one per cent pure metal worth roughly $\$ 14,000$. They are stored either in the government's own vaults or (especially in recent years) on "earmark" with the Bank of England or the Federal Reserve Bank of New York. Foreign exchange includes bank deposits abroad and holdings of short-term securities, such as the United States treasury bills held by many foreign governments, ${ }^{2}$ and commercial bills and acceptances, particularly in the United Kingdom.

Foreign exchange transactions arise when importers are paying their suppliers in the currency of the latter or when exporters are converting their earnings abroad into their own currency in order to cover their domestic operating expenses. Such transactions also arise because of capital movements among countries. Investors may purchase foreign securities because returns are higher or risks lower than those on domestic securities; or, having made such investments in the past, they may wish to invest their assets at home rather than abroad.

Finally, a currency is a commodity itself as well as a means to buy commodities or securities. Just as domestic businesses maintain cash balances at some desired level or some ratio to current spending (even borrowing so as to achieve this aim), so those engaged in foreign trade (or investments) may maintain (even at the cost of borrowing) cash balances abroad. Moreover, since world trade has been historically financed mainly in a few centers, notably London, it has often been desirable for traders to maintain bank balances in countries with which they actually have no direct commercial ties.

- The writer would like to record his thanks to J. R. T. Hughes, Jay W. Wiley, and J. Herbert Furth for numerous suggestions and corrections in the manuscript of this paper. If errors are still present, however, it will certainly be his fault, and not theirs.

+A.B. I942, M.P.A. I947, A.M. I947, Ph.D. I952, Harvard University. Associate Professor of Economics, Purdue University. Assistant Chief, Central and East European Section, Division of International Finance, Board of Governors, Federal Reserve System, 1951-54. Contributor to economic and banking publications.

${ }^{1}$ Interesting political aspects of the relations among these agencies cannot be treated in the space available. Sec, e.g., Federal Reserve System, The Treasury-Central Bank Relationship in Foreicn Countries (r95I).

${ }^{2}$ There is no very sharp line between short and long-term investments. It will be assumed here that a line can be drawn between long-term investments (including equities) and short-term securities which represent basically cash balances held in one country by residents or governments of others. 


\section{Government Foreign Exchange Transactions}

Government foreign exchange transactions are intended to maintain either a particular price structure or a particular level of international transactions. The occasion for such intervention is ordinarily that other events have undesired repercussions in the foreign exchange markets or closely related domestic economic activities. ${ }^{3}$ These events include wartime conditions, internal inflation, or depression.

The government may control foreign exchange markets in two general ways. One way is to be a buyer (or seller) always willing to carry on any volume of transactions at a stated price. ${ }^{4}$ Another way is to impose direct controls, which institute legal penalties designed to prevent sellers (or buyers) from entering the market in such a way as to cause the price or the volume of transactions to move from the desired level. ${ }^{5}$

\section{A. Price-Support Operations}

The currency of all countries is now mainly paper money, which is formally a "liability" of either the government or the central bank. ("Liability" is put in quotation marks, for in a country where paper money may not be converted into metallic, it is hard to describe the practical content of the term.) It is legal tender within the country, but not outside. If there is more than one type of currency, the various types may not be exchangeable at par. ${ }^{6}$ Nominal exchange ratios can prevail only if someone is willing and able to buy or sell any amount of one currency in exchange for others at these ratios ${ }^{7}$ or to restrict the holding of certain types of money. ${ }^{8}$ If several currencies are used in international payments, ${ }^{0}$ exchange rates will fluctuate, unless someone maintains the rates stable, either by buying and selling operations or by restricting the holding of these currencies.

All governments recognize that some international trade is necessary and desirable, and they recognize that the less the fluctuations in exchange rates, the easier will it be for traders to predict the costs and revenues from their operations,

\footnotetext{
${ }^{3}$ In extreme cases, however, control over international transactions may be an end in itself: in the Sino-Soviet bloc, state monopoly of foreign trade has been an important component of Marxist doctrine.

'In the same way, the United States Government controls agricultural prices by being willing to buy unlimited amounts of produce at a support price. Sellers will not usually sell for a lower price, since they know they may always sell to the Government at this price.

"Similarly, the Texas Railroad Commission controls the price of crude oil by limiting the amount of oil which any well-owner may pump in the course of a month.

'In the United States before the Civil War, the private banks which issued notes which circulated as money were of varying soundness and reputation, and a \$ro note on one bank would not necessarily buy the same amount of goods as a \$ro note on another bank.

${ }^{7}$ The United States Treasury must exchange at par $\$$ r bills (and other silver certificates) against silver coin, and, in fact, will exchange silver certificates for Federal Reserve notes (higher denomination paper money) in any amount.

${ }^{8}$ Thus, the United States forbids its residents to hold monetary gold inside the United States. It is thus unnecessary for the Government to do anything internally to maintain the domestic rate of exchange of paper money for gold at $\$ 35$ to one ounce (besides enforcing the prohibition).

${ }^{8}$ Forward markets and currencies which are valid only for certain purposes are cases in point.
} 
and the easier, therefore, for them to conduct foreign trade. They have, in general, preferred to stabilize exchange rates for fairly prolonged periods and to have infrequent (if necessary, abrupt) changes rather than frequent minor changes. ${ }^{10}$ They have often preferred, when faced with the threat of a temporary exchange rate instability, to limit entry into foreign exchange markets rather than permit actual fluctuations in exchange rates to take place. In some cases, government agencies have been given the sole right to hold foreign exchange.

Exchange rate policies of any one government are limited by those of others. If any one government reduces the value of its currency, it gives its exporters and domestic producers an advantage in world trade, since its goods become cheaper in foreign markets, while foreign goods become more expensive at home; simultaneously, it discourages imports. But if one country devalues, others may retaliate. Such competitive exchange depreciation was, in fact, one of the reasons for the establishment of the International Monetary Fund, which provides a forum for international consultation on exchange rate changes. ${ }^{11}$

When a government agency wishes to maintain some rate of exchange for its own currency, but sees that the price of its currency is falling, it can hold up the price by buying its own currency from foreigners, using either gold or its own foreign exchange holdings in payment. If the value of the pound is dropping in New York, the Bank of England may buy pounds in New York, using in payment funds on deposit in New York banks or buying dollars from the Federal Reserve System with gold. ${ }^{12}$

If a government has a supply of gold and foreign exchange (including what it can borrow from other countries or the International Monetary Fund) adequate to meet ordinary emergencies, and if it can expect the outflow caused by such emergencies to be offset by an inflow at some later date, ${ }^{13}$ it can meet them by its ordinary price-support operations. If the emergency is severe or protracted enough, then the authorities will allow the exchange rate to fall (since they will consider

\footnotetext{
${ }^{20}$ At the end of 1958 , Italy and Canada were the main trading countries whose currencies lacked a par value, and Italy has, in fact, stabilized its exchange rates for considerable periods.

${ }^{11}$ No country may borrow from the IMF if it has not set an initial par value for its currency without IMF objection. In fact, France devalued its currency in 1948 without Fund approval. The power to withhold loans is the main IMF weapon. Since a single violator of a price-fixing arrangement may, in fact, gain considerable advantages, it is clear that there are circumstances when the Fund's sanctions would be inadequate to deter violators. So far, the general dislike of price-cutting has prevented any major test of the Fund.

${ }^{12}$ Exporters of country $A$ with deposits in country $B$ banks draw checks on these deposits to pay for purchases of their own currency. These checks end up in the hands of the B's central bank. Checks on banks in country $A$ which these exporters receive in exchange (for deposit in their domestic bank accounts) may turn out to be checks drawn by the central bank of $B$ against its foreign accounts in country $A$. No currency in gold is ordinarily shipped from one country to the other.

${ }^{18}$ The Suez crisis of 1956 created an expectation among traders that the British would have to increase imports and reduce exports to a point where Bank of England gold and dollar reserves would not be enough to support the price of $\$ 2.80$ per $£ \mathrm{I}$. In anticipation of devaluation and/or severe restrictions on the acquisition of dollars, holders of sterling converted as much as possible into dollar balances or United States goods. The authorities, in contrast, were convinced that the emergency was temporary and sought temporary United States aid and a line of credit from the IMF. The authorities were correct, and a "return to sterling" began in late 1957 .
} 
their purchasing power insufficient to maintain it) or deny access to the foreign exchange market to some.

In the absence of government intervention or of countervailing private capital movements, an increase in a country's imports would force down its exchange rate, leading to a series of price adjustments. At the lower exchange rate, exports would tend to increase, but the internal prices of exported goods would rise to some degree to offset this cheapening. At the same time, the lower exchange rates would tend to make imports more expensive, reducing the demand for them, and hence their price abroad. Thus, internal prices in all countries and exchange rates would tend to change, with the changes being influenced also by traders' anticipations as to their magnitude and duration.

Government intervention stabilizes the exchange rate. Changes in imports of the sort just described would require the government to sell gold or foreign exchange reserves to support the exchange rates. Then, (in somewhat oversimplified terms) if the amount of money inside any country varies with gold reserves (so that an increase in a country's imports automatically decreases its money supply), and if internal prices vary with the money supply, exports will rise, imports will fall (since the price level at home is now lower), and the gold flow will tend to stop without any "structural" balance-of-payments problems-that is, problems which do not automatically correct themselves.

A country at war cannot, however, export much, since the government's internal purchases grow enormously. Its imports, however, tend to rise, because even normal internal demand cannot now be met, given government demand for goods; and wartime finance is usually inflationary, so that demand for imports rises above normal.

Likewise, an inflation not induced by war in a single country leads to rises in domestic prices (and hence reductions in exports), accompanied by increased demand for imports. These changes will force the government, if it is to maintain a given exchange rate, either to pay out gold and foreign exchange reserves or to restrict access to the foreign exchange market.

A depression in a single country has the opposite effect from an inflation. A decline in internal demand lowers prices, reduces imports (which are no longer as competitive at home), and increases the demand for exports. ${ }^{14}$ If, however, the central bank ascribes the depression to lower investment and forces down interest rates to encourage business borrowing, there may arise a demand for foreign securities, on which yields will not have fallen, and hence a need for support of the exchange rate at the cost of foreign exchange reserves. ${ }^{15}$ In general, the perversity of

${ }^{14}$ A major factor in postwar European thinking was the experience of 1929 and 1938 , when declines in United States economic activity led to flows of gold into the United States. This experience seemed repeated in 1949, when a United States recession coincided with internal inflation in the United Kingdom. It was clearly not repeated in 1954 or 1957 , when other United States recessions took place.

${ }^{16}$ In the United States recessions of $1953-54$ and $1957-58$, sharp declines in United States interest rates led American banks to move funds to London, where interest rates continued high. Thus, the United States lost gold despite the recession, rather to the surprise of most economists. Sce 40 Fed. Reserve Bull. II26, II27 (x954); 44 id. at II3I, II32 (1958). 
capital movements with respect to business cycle changes in the I930's led to a tendency by governments after 1945 to treat capital movements as being separate from commodity movements and to subject them to distinct sets of controls. ${ }^{16}$

During the early I930's, when the major industrial countries underwent more or less severe depressions, the problem of inflation assumed a special form. For any single country endeavoring to stimulate economic activity was apt to find that its efforts raised its internal price level and worsened its foreign trade position. ${ }^{17}$ The problem then seemed to be that internal recovery could be achieved only at the cost of scarce foreign exchange reserves. The elaborate exchange controls of Germany, whose recovery was primarily induced by military expenditures, were the most dramatic, but not the only, example of this phenomenon.

In all these cases, government actions in the foreign exchange markets are designed to enable the government to carry out other policies without changing the exchange rate or finding itself without foreign exchange reserves. A government is never without internal financial resources-since as a last resort, it can always print paper money-but it may be seriously handicapped for lack of foreign exchange.

In special cases, moreover, a government must even consider the actions of nonresidents. Thus, the United Kingdom has a special problem in its sterling liabilities. These represent the sterling holdings of nonresidents, only part of whom are in the Commonwealth. In I947, the United Kingdom, under United States pressure, allowed certain nonresidents the right to convert these holdings into United States currency, causing a loss of almost a billion dollars in foreign exchange reserves in a few months. The importance of London as a center for foreign deposits has had especial historic significance, but at present, a similar situation is increasingly noted in the United States. Thus, at the end of 1958 , foreign short-term assets in this country amounted to about $\$ 16,000,000,000$, while United States gold reserves totaled $\$ 20,600,000,000.18$ The chances of a general removal of these assets seem as small at present as did the chances of a liquidation of the sterling balances in England in the last century.

Thus, the stability of foreign exchange markets cannot be dissociated from government operations. The government, in the narrow sense, wants to maintain exchange rate stability without undue risk of running short of foreign exchange. But the government, in the broader sense, intervenes in these markets because its other economic operations affect and are affected by them. If it feels that its sales of gold or foreign exchange are temporary and that business conditions will alter in such a way as to enable it to stop selling gold (or even to buy back what it has sold), it may have no compelling reason to do anything..$^{19}$ If, however, all foreign exchange

${ }^{10}$ See John H. Williams, Postwar Currency Plans esp. cc. 9, it (2d ed. 1945).

${ }^{17}$ Ragnar Nurkse, International Currency Experience (1944), gives an excellent discussion of the relation between internal stability and the international position of central banks in the interwar period.

${ }^{18} 45$ Fed. Reserve Bull. 155, 210 (1959).

${ }^{10}$ The IMF distinguishes between "structural" troubles and those which will correct themselves. It will lend foreign exchange in the latter, but nat in the former situation. The problem, of course, is to diagnose a trouble correctly. 
reserves are apt to be spent, (I) the exchange rate must be abandoned as untenable, (2) exchange controls must be instituted, or (3) internal government policies leading to the loss of reserves must be abandoned. The last possibility is frequently the most efficacious, but can only be touched on here. ${ }^{20}$

\section{B. Foreign Exchange Controls}

Foreign exchange controls may be most intricate. ${ }^{21}$ They differ $(\mathrm{I})$ according to the number of control systems a country has, and (2) according to the variations in exchange rates permitted.

A control system is a rule under which a buyer of foreign exchange is permitted to use foreign exchange. ${ }^{22}$ A transaction in goods and the corresponding foreign exchange transaction are authorized within certain quantitative limits, so that the market price is available only up to a certain volume of business, even if both parties are willing to do more. ${ }^{23}$ Imports or exports beyond the limit may be allowed, subject to a penalty or premium rate of exchange. At the basic rate of exchange, however, buyers or sellers are willing to buy or sell more than they are permitted by the government.

Such control requires that no importer bring goods into the country without government consent. The only sure way of enforcing the rule is by seeing to it that only the government has foreign exchange (including gold) with which to make payments. But if exporters must sell their foreign exchange earnings to the government $^{24}$ and if registration of foreign assets ${ }^{25}$ held by residents of the country is required, normal sources of foreign exchange earnings are channeled into government accounts, and payments out of these accounts are made subject to controls.

This sort of system centralizes a country's foreign exchange in government hands. ${ }^{26}$ The government may maintain a par value on those transactions with nonresidents and conduct transactions with its own residents at prices which differ

${ }^{20}$ The discussion in this paper all runs in terms of losses of foreign exchange reserves. Actually, inflows of foreign exchange assets and gold may also provide special problems. Thus, since I950, German policy has been to try to avoid an increase in these assets without allowing price increases, which are anathema in a country whose monetary system has twice completely collapsed in forty years. The acquisition of $\$ 6,000,000,000$ in gold and foreign exchange is a remarkable achievement, and the problems caused by it, like all embarrassments of riches, are somewhat less urgent than those discussed here.

${ }^{21}$ The Annual Reports on Exchange Restrictions published by the International Monetary Fund are the most complete single cataloging of the restrictions in the postwar period. For the interwar period, sce Heinrich Heuser, Control of International Trade (1939).

22 Technically, the buyer may require a license to import foreign goods, or an authorization to pay for them in the exporter's currency, or both. Administrative problems may arise where one license, but not the other, is granted; but these will not be discussed.

${ }^{28}$ Similar controls may exist over exports, so that sales beyond a certain limit are not authorized. In Ames, Economic Integration in the European Soviet Bloc, in AM. Econ. Ass'N, Proceedings (1958), the writer has outlined some aspects of economic equilibrium in trade of this sort.

${ }^{26}$ If exports require a license, exporters may be required to deposit with the government accounts abroad a sum equal to the invoice value of their exports within a stated period after the goods leave the country. The government will then reimburse them in their own currency on the basis of their exchange-control rules.

${ }^{25}$ Such registration, however, has proved particularly hard to enforce.

${ }^{20}$ In the postwar period, over half of the United States bank deposits of foreigners have been official; and many of the private deposits are, in fact, only temporary. 
widely from the par values. It may, in principle, in trade with $n$ countries involving $m$ commodities have $n \times m$ different effective exchange rates and $n \times m$ rules governing foreign exchange transactions. The larger the number of separate controls and exchange rates, the more difficult it is to operate the system purposefully, as the greater becomes the administrative cost and the less the intelligibility of the rules to their administrators. Without actually importing and exporting on its own account, however, the government can produce an incentive for private businesses to execute many of the same transactions a government trading agency would carry on in its own name.

The first major type of exchange control is a control over the selection of partner countries (or, more properly, currencies) by residents engaging in foreign trade. Countries where internal prices are high (relative to exchange rates) are more attractive as markets for exports and less attractive as sources of imports. Such countries, however, are apt to be countries which themselves have exchange controls. That is, their governments refuse to provide third currencies to importers, so that their trading partners will be forced to buy from them as well as sell to them (thus reducing the pressure on their foreign exchange reserves). Just as devaluation may provoke retaliation, so may exchange controls. If country $A$ normally uses its exports to $B$ to pay for its imports from $C, B$ 's exchange controls may interfere with this transfer and perhaps lead $A$ to limit its trade with $B$, unless $B$ permits transfer.

This tendency toward bilateral trade and exchange controls in Europe after World War $\mathrm{II}^{27}$ was only gradually overcome, as European economic conditions improved, using the Organization for European Economic Cooperation and later its offspring, the European Payments Union. A general reduction in European exchange rates (increase in European gold prices) in September I949 provided a rough correction for the greater wartime price rise in Europe than in the United States, so that in 1950, the European Payments Union re-established, with some limitations, general multilateral exchange within Europe. Restrictions on trade with the United States and Canada continued, but were gradually relaxed, since the prices in these countries rose more rapidly in the I950's than European prices, reducing the pressure on European reserves. $^{28}$ At the end of $195^{8}$, most of the remaining controls on the ability of nonresidents to convert European balances into dollars were removed, and restrictions on European trade with dollar countries were lessened. Thus, this type

${ }^{27}$ In considerable degree, European prices were abnormally high because of wartime demand inflation and damage to plant. Reconstruction was, of course, speeded by United States Government aid, a subject of great importance, but beyond the scope of this paper. Greater European output would, in these circumstances, decrease (rather than increase) demand for United States goods, tend to increase exports, as plant resumed production, and thus decrease the general pressure on European exchange reserves, permitting decreases in exchange controls.

${ }^{28}$ At the end of 1950 , the United States had gold reserves of $\$ 22,800,000,000$, and European countries had $\$ 7,300,000,000$ plus $\$ 2,900,000,000$ in short-term claims on the United States. At the end of 1958, the United States had gold reserves of $\$ 20,600,000,000$, and European countries had $\$ 13,400,000,000$ plus $\$ 7,800,000,000$ short-term claims on the United States. International Financial Statistics, March 1959 , pp. 16,36 . 
of control, which predominated in the early postwar period, has become relatively unimportant.

A second major type of exchange control is over the types of commodity in foreign trade. This control is particularly important in so-called underdeveloped countries, where governments are trying to industrialize more rapidly than business processes would normally allow. In such a country, higher-income groups tend to buy foreign goods or land rather than invest in domestic industry; and any investment requires imports of capital goods. Government investment is apt to be financed by inflation (where there is no local capital market or a poorly developed tax system), so that the programs lead not only to large capital goods imports, but also to increased luxury consumer goods imports; and exports tend to be priced out of world markets.

The exchange-control system in these countries, then, offers favored rates to importers of capital goods and to exporters, so as to permit the government to avoid the drain on foreign exchange of its development program. With the general improvement in the European payments situation since 1949, this type of exchange control is probably the most prevalent today. ${ }^{29}$

Whether the controls be set up by country or by commodity, licensing involves (I) selection of firms eligible to receive licenses, and (2) periodic changes in licenses given to any category of trader. Very complicated questions of law arise in daily administration of such systems, and they cannot be treated here.

Two special types of control should be mentioned, albeit without much discussion. The first connects an import to an export transaction: businesses producing for sale in a low-cost (hard-currency) area may purchase raw materials in low-cost areas or even receive a general import license as a reward for their sales; or importers from high-cost (soft-currency) areas may receive some low-cost area license as a reward for their efforts. The second permits unlimited sales or purchases of foreign exchange of certain areas (or for certain purposes), the price of the exchange being, however, at a rate which is allowed to vary with demand and supply. Thus, the government might fix an exchange rate for necessary imports and allow that on luxuries to fluctuate.

Two consequences of exchange-control systems should be indicated. The first is that the internal prices of a country may vary without reference to variations in world prices. Where domestic prices would ordinarily be conditioned by world prices (since importers and exporters alike will take advantage of differentials, when

${ }^{20}$ One reflection of the change in the nature of global exchange controls is found in the geography of United States foreign aid. Whereas in 1949 , the United States spent $\$ 4,500,000,000$ in forcign aid to Europe and $\$ 1,300,000,000$ in aid to Asia, the corresponding figures (excluding military aid) in 1957 were $\$ 5,000,000,000$ and $\$ 1,700,000,000$, respectively. Survey of Current Business, April 1950, p. 20; id., April I958, p. 22. Moreover, while European gold and foreign exchange reserves were rising, as indicated in note 28 stipra, Asiatic reserves fell from $\$ 4,400,000,000$ to $\$ 4,100,000,000$. These changes correspond roughly to (I) the solution of wartime inflationary problems in Europe, and (2) the appearance of inflationary development finance in Asia. 
permitted to do so, thereby limiting price differences), exchange controls break this link.

The second consequence is the involvement of the government in exchange equalization. ${ }^{30}$ Even if import and export licenses balance international payments without changes in gold and foreign exchange reserves, the government still has to settle with businesses in its own country. That is, it collects domestic money from importers (who have bought foreign currency from the government) and sells domestic money to exporters (in payment for the foreign currency they have earned). In order to encourage exports and discourage imports, so as to reduce the drain on its foreign exchange reserves, a government may pay a premium on the former and a penalty on the latter; this means an implicit devaluation.

If the controls are successful, they create domestic industries which may never be able to compete successfully on world markets. If the government later wishes to remove the controls, it may find important internal vested interests to oppose it. If domestic and world prices differ, the government may have to subsidize export industries or find itself dependent on profits earned from the sale of imports internally. Concentration of foreign exchange in government hands thus isolates internal prices from world prices and has important and complex internal repercussions. The most enthusiastic proponents of exchange controls would argue that there are cases where the pattern of resource utilization thus achieved can be more desirable than that which would be achieved otherwise. Particularly in the underdeveloped countries, the view is held that economic development (industrialization) requires the abandonment of market processes and hence exchange controls.

It is, of course, hard to determine the effectiveness of these various control systems. Even under as elaborate and efficient controls as those of the United Kingdom in the late 1940's, traders were apparently able to move up to $\$ 400,000,000$ and an equal amount in European currencies in and out of the United Kingdom, merely by shifting from thirty-days' arrears to thirty-days' prepayments on ordinary commercial transactions (the Bank of England could not control these transactions more closely within the limits of ordinary business practice) and cause very great erratic shortterm shifts in British reserves. ${ }^{31}$ And there is ample evidence that countries plagued by persistent monetary expansion have found it most difficult, even with controls, to prevent imports from rising more than exports. ${ }^{32}$ An extensive controversy has raged between those who have maintained that exchange controls were primarily a reflection of monetary inflation and would be unnecessary in a country with ade-

\footnotetext{
${ }^{30}$ The writer attempted a concise explanation of the fiscal consequences of separating domestic and international prices in Ames, The Exchange Rate in Soviet-Type Economics, 35 REv. Econ. \& STrT. 337 (I953). This article explains the bookkeeping of a conceptually simple system of complete controls, which is perhaps useful in understanding the more complex cases here discussed, where internal and world prices are more or less free to fluctuate.

${ }^{32}$ Sec Katz, Leads and Lags in Sterling Payments, 35 Rev. Econ. \& Star. 74 (1953).

${ }^{33}$ How else can one explain the persistent failure of efficient governments of law-abiding populations to avoid undesired losses of foreign exchange, as in England from 1945-50 and Scandinavia generally since 1945 ?
} 
quate credit controls, ${ }^{33}$ and those who have maintained that exchange controls reflected mainly nonmonetary difficulties within the country which might be expected to continue to threaten a country's foreign exchange reserves regardless of the monetary policy it might pursue. ${ }^{34}$

Final resolution of the dollar-shortage problem into monetary and nonmonetary components would be a monumental task and cannot be undertaken here. ${ }^{35}$

II

\section{Foreign Exchange Assets}

All exchange-control systems concentrate foreign exchange in government hands and thereby raise interesting political problems. On the one hand, a government's foreign exchange is a bank deposit and is of interest to foreign exchange-control authorities. If these choose, they can freeze it, cause it to be depreciated, limit payments from it, and so on. On the other hand, one government cannot injure other. governments without inviting retaliation. A system of protocol among central bankers has developed to eliminate petty irritations, although, of course, major differences of interest cannot be easily settled. ${ }^{36}$ The possibility of such retaliation increases the desirability of having gold rather than currency as a country's reserve.

The analysis of a country's foreign assets is somewhat deceptive, for similiarities in procedure may conceal important differences in substance. In the absence of exchange controls, a country's foreign assets indicate earnings which are an effective source of purchasing power. However, with exchange controls, quite a different situation may exist. Thus, during World War II, the Germans made large purchases in Danubian and Balkan countries (and had considerable military expenses for troops stationed there). These expenses were paid for in marks and credited to bank accounts in the names of the respective countries, increasing the foreign exchange assets of the latter. On the other hand, the bank accounts could not be used, and the transaction had the same nature as loans to Germany. German purchases, moreover, had internal inflationary consequences in these countries. It seems unlikely that these countries would have wished to finance Germany to this extent in the absence of German troops in their vicinity. ${ }^{37}$

\footnotetext{
${ }^{33}$ The annual reports of the Bank for International Settlements (Basle) are perhaps the most effective current analyses from this point of view.

34 The annual Economic Survey of Europe, published by the United Nations Economic Commission for Europe (Geneva), provides forceful expression of this view, particularly in the first decade after the war. See also British Labor Party viewpoints, as expressed notably by Gaitskell, Kaldor, and Balogh. Thomas Balogh, The Dollar Shortage (1949), in particular, provides an early statement of this nonmonetary view.

- 35. See'Furth, The World Dollar Problem, in World Pouitics 262 (1959).

${ }^{80} \mathrm{~J}$. W. BEYEN, -MONEY IN a MAELSTRom (1949), gives a combination of personal reminiscences and monetary analysis in which these aspects of international central banking are prominent. The author has played a prominent role in Netherlands central banking and also in the Bank for International Settlements and the International Monetary Fund.

$r_{x}^{i}, 87$ The wartime annual reports of the Barik for International Settlements are still the best source on this subject.
} 
On the other hand, many members of the British Commonwealth allowed their balances with the Bank of England to rise greatly during the war, although Canada provided aid in a form basically analogous to lend-lease. Australian contributions to the United Kingdom during the war would not differ in form from Hungarian contributions to Germany; but the substance was different. While Canadian aid was in the nature of a donation, the sterling balances of the other Commonwealth countries were, in effect, loans, and they have been to a considerable extent repaid to enable them to finance postwar import surpluses.

The United States has never had exchange controls for balance-of-payments reasons, and for many years, it has been the largest owner of gold in the world. There has been no compelling reason for the United States Government to keep foreign balances for monetary purposes. However, since World War II, the United States Government has been involved in foreign exchange transactions for a variety of reasons. First, a large military establishment has been maintained abroad. Currency of the countries in which these troops are stationed is needed partly to pay the troops and partly also to pay local costs, including the construction of installations. Second, national security policies have permitted offshore procurement: the United States wishes to aid the defense program of country $X$; it purchases arms for $X$ in country $Y$; it must, therefore, from time to time, make purchases of $Y$ 's currency in connection with the aid program. The administrative arrangements under these headings are, of course, complicated in detail, and need not be dwelt on here. Some $\$ 1,100,000,000$ was spent on offshore procurement in $1956-57^{38}$

Third, the United States has been involved with a series of foreign central-bank balances which may be called counterpart funds. A government receiving United States aid under some programs deposits the local currency equivalent of the aid in special accounts, which may not be used without mutual agreement. Where these funds are the result of selling aid goods to the public, increases in counterpart reduce the cash assets of the public, and countries with inflationary problems have sometimes left the funds on deposit, or even used them to retire part of the public debt held by the central bank, so as to prevent their returning into circulation (this latter alternative is not now possible). Alternatively, they may be used as a substitute for tax revenue by the recipient of the aid. The United States normally claims credit for such internal expenditures, as having been financed by the proceeds of United States grant aid.

In recent years, the United States has particularly encouraged foreign countries to purchase surplus agricultural commodities by accepting payment for them in counterpart funds rather than in United States dollars, so that a country may increase its purchases from the United States without a drain on its exchange reserves. ${ }^{39}$ This has the political advantage for the United States of causing farm goods in

\footnotetext{
${ }^{38}$ Survey of Current Business, April 1958, p. 2 r. Id. at 20 .

${ }^{30}$ In $1957 \$ 600,000,000$ net of such purchases took place out of total nonmilitary aid of $\$ 2,300,000,000$.
} 
United States Government hands to disappear without spoilage, on the one hand, or the appearance of a "giveaway," on the other. The foreign country, in its turn, receives dollar purchasing power without either precisely accepting a gift or yet promising to pay dollars for it. And while the United States acquires foreign balances which are in some degree frozen-since they cannot, under international agreement, either be converted into dollars or used to pay for ordinary imports of the United States-its position with respect to the recipients of the surplus goods can hardly be compared to that of the Balkan countries with respect to Germany, or of Commonwealth countries with respect to the United Kingdom. ${ }^{40}$

\section{ConCLUSIONS}

The commitment to maintain a stable exchange rate and the need for foreign exchange have close connections with the entire course of a country's internal economic process. Internal events and, of course, the country's foreign policy taken in the broad sense have repercussions upon the country's foreign exchange reserves. These constitute the means by which the state can carry out its intentions internationally.

Analysis of these transactions inevitably, then, raises in technical terms the question of whether a country's internal economic development (influenced as it is by government action) is compatible with its international situation. As might be expected, it is not always easy to determine which affects which. In some sense, the absence of government action here implies a situation satisfactory to the government; but it cannot be inferred from the fact of government action whether the disturbance arises from without or within.

A considerable part of the technical interest of the subject lies in the difficult problem of deciding the precise consequences of any particular rule which a state may set forth governing its operations in gold and foreign exchange. Usually, a considerable variety of measures may have the same net effect on a country's international payments. In this case, then, the selection of a particular policy with regard to state transactions in gold and foreign exchange must be examined in terms of the government's internal objectives, given the state of the world economy. The transactions here mentioned have effects on the way internal economic processes work, so that it is quite possible for a country's internal and international economic policies to be in conflict. In this event, the decision as to whether internal or international considerations must prevail will depend upon the realities of the situation and the strength of the government's various commitments. at 22 .

10 At the end of 1957, the United States had about $\$ 1,700,000,000$ of these foreign exchange assets. Id. 